\title{
An interesting case of lymphadenopathy
}

\author{
Preet Mukesh Shah, ${ }^{1}$ Abhijeet Prasad, ${ }^{2}$ Vijay Waman Dhakre ${ }^{3}$
}

'Department of Critical Care, Jaslok Hospital and Research Centre, Mumbai, Maharashtra, India

${ }^{2}$ Department of General Medicine, Jaslok Hospital and Research Centre, Mumbai,

Maharashtra, India

${ }^{3}$ Department of Liver Diseases, Global Institute of Liver Diseases, HPB Surgery and Transplantation, Mumbai, Maharashtra, India

\section{Correspondence to} Dr Vijay Waman Dhakre, vddrvijayd@gmail.com

Presented as a poster at APICON 2017

Accepted 23 April 2018

Check for updates

To cite: Shah PM, Prasad A, Dhakre VW. BMJ Case Rep Published Online First: [please include Day Month Year]. doi:10.1136/bcr-2018224745

\section{DESCRIPTION}

A 43-year-old man, a known case of diabetes mellitus and hypertension (both well controlled), with no history suggestive of high-risk sexual behaviour, presented with a painless swelling over the left side of the neck since 30 days which was insidious in onset and gradually progressive; fever since 15 days which was of sudden onset, intermittent, relieved with medications and was associated with generalised bodyache; diarrhoea since 3 days which was sudden in onset, foul smelling, watery, non-bloody, 7-8 episodes per day. He had lost $4 \mathrm{~kg}$ of weight in 15 days. He was a vegetarian, did not keep cats as pets and was not known to be having an immunocompromised state.

On clinical examination, only the lymph nodes in the posterior triangle of the left side of the neck were palpable. These were non-tender and were not matted.

Investigations showed anti-toxoplasma antibodies IgM and IgG (done by ELISA method) both to be positive. Cytomegalovirus and Rubella IgM were negative. Erythrocyte Sedimentation Rate, stool routine examination and culture, MRI brain were all normal and HIV ELISA was negative. Funduscopy was normal. Surgical excision of the lymph node was done, and the histopathological analysis (figure 1) showed areas of necrosis containing epithelioid histiocytes. These areas were surrounded by lymphocytes and plasma cells. There were no granulomas. He did not agree to send his serum sample to a reference laboratory to test for toxoplasmosis in view of his financial condition. Considering his serological and histopathology findings, a diagnosis of toxoplasma lymphadenitis was made, and he was started on sulfadiazine and pyrimethamine, after which his symptoms gradually improved.

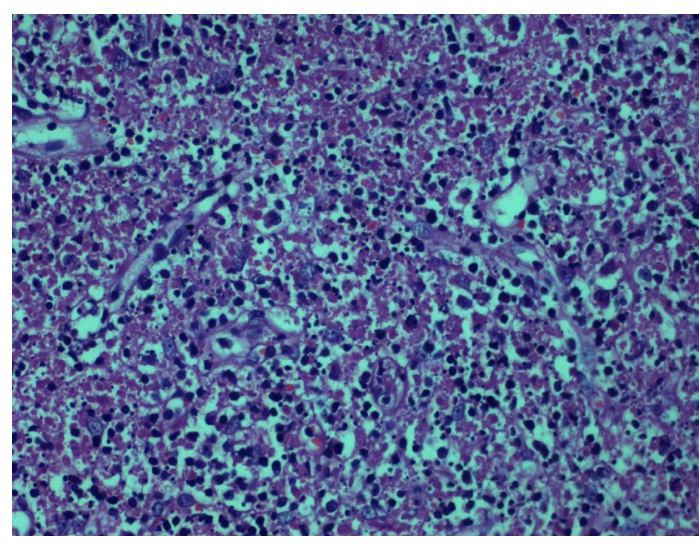

Figure 1 Histopathological analysis of excised lymph node showing areas of necrosis containing epithelioid histiocytes, with these areas being surrounded by lymphocytes and plasma cells. Absence of granulomas.

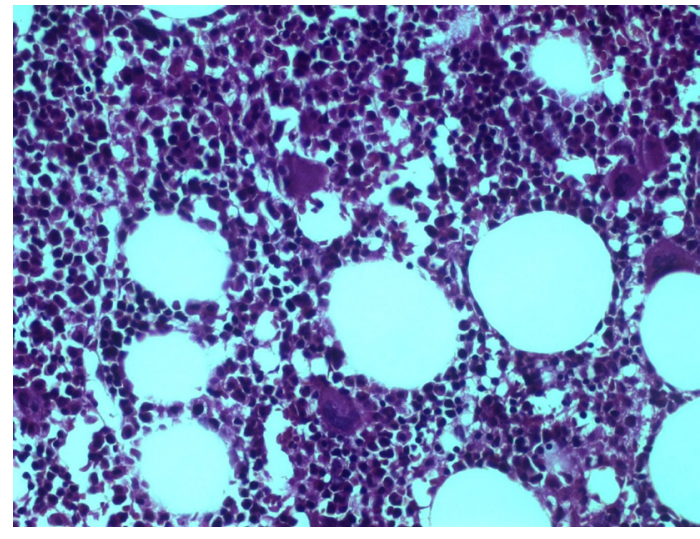

Figure 2 Bone marrow examination showing normocellular marrow with trilineage haematopoiesis.

A month later, he presented with fever with chills and rigors since 5 days; nausea and vomiting since 2 days. Complete blood count showed leucopenia (white blood cell count of 3100 cells $/ \mathrm{mm}^{3}$ ). His Anti-nuclear antibody and anti-dsDNA were both positive, and bone marrow examination (figure 2) showed normocellular marrow with trilineage haematopoiesis. Positron emission tomography-computerised tomography scan (figure 3) showed increased uptake in multiple cervical, supraclavicular, axillary, abdominal, retroperitoneal and pelvic nodes. Correlating these findings a diagnosis of systemic lupus erythematosus (SLE)-associated necrotising lymphadenitis was made. He was thus started on prednisolone, and his anti-toxoplasmosis medication continued. Gradually his fever subsided and his overall condition and symptoms improved.

Toxoplasmosis, caused by Toxoplasma gondii, which is an intracellular parasite, is a disease that usually affects an immunocompromised host. In immunocompetent individuals, most infections are asymptomatic, but the most common manifestation is cervical lymphadenopathy which is seen in about $10 \%$ cases. $^{1}$

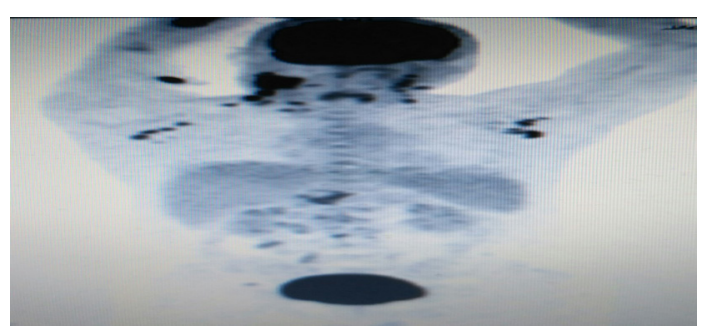

Figure 3 Positron emission tomography-computerised tomography scan image showing increased uptake in multiple cervical, supraclavicular, axillary, abdominal, retroperitoneal and pelvic nodes. 
Lymphadenopathy associated with SLE has a prevalence of $5 \%-7 \%$ and usually involves the axillary and cervical nodes. ${ }^{2}$

This is an interesting case as our patient had lymphadenopathy due to two unrelated aetiologies at different points of time. The presence of lymphadenopathy by itself due to these aetiologies is not uncommon; however in our patient, it was the focal point to detect these two different aetiologies, one following the other.

\section{Learning points}

- Positron emission tomography-computerised tomography scan is a useful investigation to evaluate cases of fever where the diagnosis is difficult despite extensive evaluation.

- Location of the enlarged lymph nodes is a useful guide to narrow down the possible aetiologies of the lymphadenopathy.
Contributors PMS wrote the case history and discussion of the case. VWD assisted in the discussion of the case. AP acquired the clinical images relevant to the case.

Funding The authors have not declared a specific grant for this research from any funding agency in the public, commercial or not-for-profit sectors.

Competing interests None declared.

Patient consent Obtained.

Provenance and peer review Not commissioned; externally peer reviewed.

(C) BMJ Publishing Group Ltd (unless otherwise stated in the text of the article) 2018. All rights reserved. No commercial use is permitted unless otherwise expressly granted.

\section{REFERENCES}

1 Taila AK, Hingwe AS, Johnson LE. Toxoplasmosis in a patient who was immunocompetent: a case report. J Med Case Rep 2011:5:16.

2 Neto NS, Bonfiglioli KR, Milanez FM, et al. Lymphadenopathy and systemic lupus erythematosus. Rev Bras Reumatol 2010;50:96-101.

Copyright 2018 BMJ Publishing Group. All rights reserved. For permission to reuse any of this content visit http://group.bmj.com/group/rights-licensing/permissions.

BMJ Case Report Fellows may re-use this article for personal use and teaching without any further permission.

Become a Fellow of BMJ Case Reports today and you can:

- Submit as many cases as you like

- Enjoy fast sympathetic peer review and rapid publication of accepted articles

- Access all the published articles

Re-use any of the published material for personal use and teaching without further permission

For information on Institutional Fellowships contact consortiasales@bmjgroup.com

Visit casereports.bmj.com for more articles like this and to become a Fellow 